\title{
Al-Maqrizi (d.1442) and Abd Al-Basit (d.1514) and Their Accounts on the Economy of Egypt
}

\author{
Wan Kamal Mujani \\ Dept. of Arabic Studies \& Islamic Civilization \\ Faculty of Islamic Studies, UKM \\ 43600 Bangi, Selangor, Malaysia \\ inamal@yahoo.com
}

\author{
Noor Inayah Yaakub \\ School of Management \\ Faculty of Economics \& Management, UKM \\ 43600 Bangi, Selangor, Malaysia \\ inayahyaakub@gmail.com
}

\begin{abstract}
The aim of this article is to discuss about the life of AlMaqrizi (d.1442) and Abd Al-Basit (d.1514) and their accounts on the economy of Egypt. In order to elaborate these matters, a sketch of their biographies will be given, and this is then followed by a discussion of the economic data conveyed by them.
\end{abstract}

Keywords-Al-Maqrizi; Abd Al-Basit; historians; economy; Mamluk; Egypt

\section{INTRODUCTION}

Economics is said to contribute to history itself, to an understanding of the evolution of human societies in the past. A discussion concerning economic history necessarily draws on economic theory since economic history has been well defined as a part of history which requires certain knowledge of economics for its full understanding. Research on economic history also depends on data related to the chosen period. Needless to say, the discussion of economic history in the medieval period encounters difficulties such as the lack of relevant data on the economy. One of the reasons for this is that most of the historians during this period did not give a complete description of the economic situation. All data on economics merely appeared in works on political history and biographies. Information on trade and commerce, currency and goods pricing were not perfectly narrated. Even though, the Mamluk historians such as Al-Maqrizi and Abd Al-Basit give scattered and incomplete information on economy, but the combination of all of these data enlighten us on a general opinion about the economy of Egypt and its situation.

\section{AL-MAQRIZI'S BIOGRAPHY}

Taqi Al-Din Abu Al-Abbas Ahmad bin Ali bin Abd AlQadir, known as Al-Maqrizi, was born in Cairo in 1364. His family came from Ba'labak which is now situated in Lebanon. They migrated to Egypt before the reign of Sultan Al-Ashraf Sha'ban (1363-1377), the third last of the Turkish Mamluk rulers. Al-Maqrizi was brought up in a well-known scholarly family. His paternal grandfather, Abd Al-Qadir (d.1332) was an eminent savant in the jurisprudence of the Hanbali sect. His maternal grandfather, Al-Shaykh Shams Al-Din Muhammad (d.1375) was a jurist at the court in 1364 and a teacher of the jurisprudence of the Hanafi sect at the Mosque of Ibn Tulun in 1373. Meanwhile, Al-Maqrizi's father, Ali, served in various posts in the judiciary and also as a secretary in the chancery [1].

UKM Research Development Fund (Grant No. DPP-2013-158)
Besides his early education from members of his family, Al-Maqrizi studied at the University of al-Azhar and was taught various subjects, such as jurisprudence, prophet's traditions, theology, literature, Arabic and mathematics by prominent Egyptian scholars. Among his masters were AlBurhan Al-Amidi, Abu Ishaq Al-Tanukhi and Ibn Abu AlMajd. Nevertheless, Al-Maqrizi's main teacher, who greatly influenced his ideas and way of historical writing, was Ibn Khaldun. This was conceded by Al-Maqrizi himself when he said that he was impressed by Ibn Khaldun and his book, AlIbar wa Diwan Al-Mubtada wa Al-Khabar [2].

Al-Maqrizi was appointed to a variety of posts, involving administrative and scholarly functions, since he possessed wide knowledge and great skill. Among the posts that he held in Egypt were chief administrator at the Mosque of Al-Hakim AlFatimi, professor in School of Al-Mu'ayyadiyya, preacher at the Mosque of Amr bin Al-As and market inspector of Cairo and Lower Egypt [3]. When he was in Syria (1408-1418), he served as a professor at School of Al-Ashrafiyya, as chief financial administrator of the Kalansiyya and administrator of endowment at the great Nuri hospital. In the reign of Sultan AlNasir Faraj, Al-Maqrizi was offered the post of judge of Damascus, but he refused. During his stay in Mecca, he was appointed professor of prophet's traditions at Masjid al-Haram. Nevertheless, after the 820 s, he never held any position and devoted himself to historical writing. He took this decision as he was dissatisfied with the Mamluk's official policy.

\section{AL-MAQRIZI's ACCOUNTS ON THE ECONOMY OF EGYPT}

Al-Maqrizi was the most famous Egyptian historian in the period of the Circassian Mamluks. His credibility in the field of history can be seen from his works and his distinguished pupils such as Abu Al-Mahasin Yusuf bin Taghri Birdi. He wrote in a frank manner and not for the sake of money. Although he had a close relationship with Sultan Al-Zahir Barquq, Sultan AlNasir Faraj, Amir Yashbak Al-Dawadar and Sultan Mu'ayyad Shaykh, this did not prevent him from criticising the attitudes and policies of the Circassian Mamluk rulers. His comments can be found in Ighathat Al-Umma, Al-Khitat and Al-Suluk. In fact he stood out as the most vocal critic of Circassian economic policy [4].

Al-Maqrizi wrote more than one hundred works, including books, short monographs and encyclopaedia. Most of his works deal with history and can be classified into three areas namely, 
general Islamic history, the history of Egypt, and the history of Prophet Muhammad (pbuh). The works that relate to the economy of Egypt are Ighathat Al-Umma bi Kashf AlGhumma, Al-Mawa'iz wa Al-I'tibar fi Dhikr Al-Khitat wa AlAthar and Al-Suluk li Ma'rifat Duwal al-Muluk. These three books show his depth of interest in the economy and they were based on his extensive knowledge and broad experience during his service for the Mamluk administration, especially when he was an inspector of market, because this post exposed him to the current situation at that particular time. These works also demonstrate his concern with the social history of Egypt and its people who always faced difficulties in their lives [5].

These books are very important because they contain information about the roots of economic decline in the early period of the Circassian Mamluks. Thus they assist in providing an understanding of the Circassian Mamluks' economic situation, especially in relation to agriculture, trade, money, currency, prices, natural disasters, government policies, and so on. Al-Maqrizi wrote Ighathat Al-Umma bi Kashf AlGhumma based on the economic crisis in Egypt in 1403. It was completed at the end of that crisis in July 1405. The main purpose of Al-Maqrizi in composing this book was to describe the factors which led to the economic crisis and how this catastrophe influenced the people at that particular time. According to Al-Maqrizi, maladministration, the heavy taxation of the peasantry by fief holders and the unorthodox financial practices of the rulers were the main factors in this crisis. Bribery had resulted in unqualified persons being appointed as higher officials such as market inspectors. Agricultural production had been decreasing since the cost of plantation activities such as ploughing, sowing and harvesting had increased. Consequently, the majority of the land remained uncultivated. The widespread circulation of copper coins following the cessation of the minting of silver coins in Egypt caused the high prices. This phenomenon had been affecting the society and the economy. In his book, Al-Maqrizi mentions in detail the currency, exchange rates, food prices and the measures which had been taken at that time [6]. This information helps to provide an understanding of economic conditions in the early part of the Circassian Mamluk period.

Al-Mawa'iz wa Al-I'tibar fi Dhikr Al-Khitat wa Al-Athar which was composed between 1415 and 1424 is the most famous of Al-Maqrizi's works. This treatise, which is commonly referred to as Khitat, deals with the topography of some cities in Egypt in the $15^{\text {th }}$ century. Al-Maqrizi discusses not only the geographical history of those cities but combines this material with detailed data on social, economic and politic matters [7]. This method of writing is more profound than that found in earlier treatises such as that of Ibn Abd Al-Hakam (d.870), Al-Musabbihi (d.1029) and Ibn Al-Tuwayr (d.1220). Meanwhile, the later writers on Khitat, such as Abd AlRahman bin Hasan Al-Jabarti (d.1822) and Ali Mubarak (d.1893), do not contribute new information. They only extract material from and summarise the book.

Al-Mawa'iz wa Al-I'tibar fi Dhikr al-Khitat wa Al-Athar is essential in this article because it contains much economic data especially on agriculture. Al-Maqrizi described the irrigation system, the agricultural land, agricultural practices, agricultural techniques, the crops grown in particular seasons, agricultural productivity, kinds of soils and the measurements used in the agriculture system. He also wrote about the exchange rate, the bazaars and market places of that time. However, he did not deal with all the agricultural land and tools which were used by the peasants in their cultivation [8].

The third book, Al-Suluk li Ma'rifat Duwal Al-Muluk, known as Al-Suluk, is about the politics, economy and society of the Circassian Mamluks until 1441. It contains abundant information regarding the economy, especially monetary and price data. Al-Maqrizi also gave accounts of the depreciation of agriculture and the government policies which depressed the merchants and led to the lessening of trade and commerce. It is worth noting that, in this material we can find an account of how the common people reacted to the economic problems. There were riots and violence each time there were shortages of food, extra taxes, changes in the value of the currency and unpopular decrees issued by sultans. In general, this book shows Al-Maqrizi's sharp criticism of the rulers. It also shows his concern for reporting the hardship suffered by the civilians.

\section{ABD AL-BASIT'S BIOGRAPHY}

Abd Al-Basit bin Khalil bin Shahin Al-Malati was born in Malatya in 1440. His family was from the upper class and members from it held various important posts during the reign of the Circassian Mamluks. His grandfather, Shahin was a provincial governor of Jerusalem, while his father Khalil occupied the vizierate in Egypt and at several times was a provincial governor in Aleppo, Safad, Kirk, Jerusalem, Malatya and Alexandria. Moreover, Khalil was well known as a learned and knowledgeable person in fields such as jurisprudence, history, literature, and medicine [9]. Khalil also wrote more than thirty books the most famous of which is Zubdat Kashf Al-Mamalik wa Bayan Al-Turuq wa Al-Masalik.

As an Awlad Al-Nas (the sons of Sultans and Amirs who was born as free men), Abd Al-Basit had the opportunity to receive a comprehensive and proper education. At an early stage, his father educated him. He later learned various kinds of knowledge from numerous eminent scholars in Damascus, Tripoli, Tunisia, Algeria, Morocco, Spain and Egypt. Among his masters in jurisprudence in Damascus were Qawam Al-Din Al-Hanafi (d.1454), Hamid Al-Din Al-Nu'mani (d.1462) and Al-'Ala' Al-Rumi. While in North Africa and Spain, he learned grammer, philosophy, and medicine. In Egypt, he learned Arabic and other subjects from prominent scholars at that time such as Najm Al-Din Al-Qirmi (d.1455), Ahmad bin Muhammad Al-Shamni (d.1467), Al-Sharaf Yunus Al-Rumi, Ibrahim bin Muhammad Al-Dayri, and Al-Kafiyaji [10].

With this educational background, Abd Al-Basit emerged as one of the most famous scholars in Egypt. According to his student, Ibn Iyas, he was famous in the jurisprudence of the Hanafi sect, in medicine, history, and other subjects. There are seventeen of his works which discuss these subjects. However, despite his ability in Turkish and his holding a respected position among the rulers, he is reported never to have held any administrative position as had his father and grandfather except as a teacher in the School of Shaykhuniyya. Unlike Ibn Taghri Birdi and Al-Sayrafi (d.1495), Abd Al-Basit never received any comments and criticism from Al-Sakhawi [11]. 


\section{ABD AL-BASIT's ACCOUNTS ON THE ECONOMY OF EGYPT}

Abd Al-Basit's works that relate to the economy of the Circassian Mamluks in Egypt are Al-Rawd Al-Basim fi Hawadith Al-Umr wa Al-Tarajim and Nayl Al-Amal fi Dhayl Al-Duwal. These two works are to be found in manuscripts form. Al-Rawd Al-Basim fi Hawadith Al-Umr wa Al-Tarajim is held by the Vatican Library and numbered Vat. Ms. 728 and Vat. Ms. 729. The first covers the introduction and events over a six-year period, from 1440 to 1446, and the second covers the years from 1460 to 1469 . Manuscript no. 729 contains 260 folios. Each folio measures $27.5 \times 18.5 \mathrm{~cm}$ and has thirty-three lines. Abd Al-Basit wrote these manuscripts himself and the work was completed on 5 April 1485 [12]. The information on the economy of Egypt in these manuscripts are not much different from that given by Ibn Taghri Birdi and Al-Sayrafi such as regards the staple crops, food prices and the Nile flood levels [13].

Another manuscript, Nayl Al-Amal fi Dhayl Al-Duwal is held by the Bodleian Library in Oxford and consists of two volumes. The first is numbered Hunt. 285 and comprises the introduction and the period from 1343 to 1436 . The second is numbered Hunt. 610 and consists of 404 folios. Each folio measures 33 x $24 \mathrm{~cm}$ and has twenty-one lines. These manuscripts were written in 1635 and cover the years 1437 to 1490. Nayl Al-Amal fi Dhayl Al-Duwal was written by Abd Al-Basit with the intention of continuing the book Duwal AlIslam which was written by Shams Al-Din Al-Dhahabi.

The second volume of the Nayl Al-Amal is a summary of Al-Rawd Al-Basim fi Hawadith Al-Umr wa Al-Tarajim. The information that relates to the economy of Egypt in Nayl AlAmal is also similar to that given by other historians. Since this book records the events that occurred until 1490, however it provides information on later years. Among the information given by Abd Al-Basit is that concerning staple crops and the prices of such as wheat, barley, broad beans, bread, mutton and beef [14].

Abd Al-Basit also wrote accounts of the expenses that were allocated by Sultan Al-Ashraf Qaytbay for the military campaigns in fighting Shah Suwar and Hasan Al-Tawil until both were defeated. He also mentions the preparations made by Sultan Al-Ashraf Qaytbay in fighting the Franks who entered Alexandria and seized trade vessels and market goods [15].

Abd Al-Basit reports in detail about the plagues that took place in 1476 and which caused high mortality not only among civilians but also the Mamluk armies. The havoc caused by Bedouins is also reported. Beginning in 1473, Abd Al-Basit narrates the story of the rebellions carried out by the Mamluk Julban (the Mamluks of the ruling sultan) who were dissatisfied with their treatment and demanded higher wages. Several points relating to the agricultural sector in Egypt, such as the Nile floods and natural disasters, are also mentioned [16].

Nevertheless, Nayl Al-Amal does not convey continuous information from year to year and in fact there are breaks in information for several years. Abd Al-Basit also does not refer to the industrial and commercial sectors at that time. On the whole, information given by him sometimes appears exaggerated and needs to be carefully examined.

\section{CONCLUSION}

There were many prolific historians during the Mamluk period and they contributed to the development of Mamluk historiography by documenting information about society, politics and the economy during their times. The works of these historians were, however, focused more on social and political history than economy. Most of the historians during this period such as Al-Maqrizi and Abd Al-Basit did not give a complete description of the economic situation. All data on economics merely appeared in works on political history and biographies. Information on agriculture, industry, commerce and the monetary system was not given in detail. However, the combination of all these data can give us a general idea about the economy of Egypt and its situation during the period under consideration.

\section{ACKNOWLEDGMENT}

This research study is sponsored by a grant of Research Development Fund, Universiti Kebangsaan Malaysia (Grant No. DPP-2013-158)

\section{REFERENCES}

[1] Adel Allouche, Mamluk Economics - A Study and Translation of AlMaqrizi's Ighathah, Salt Lake City: University of Utah Press, 1994.

[2] Al-Maqrizi, Al-Mawa'iz wa Al-I'tibar fi Dhikr Al-Khitat wa Al-Athar, London: Mu'assasat Al-Furqan lil Turath Al-Islami, 1995.

[3] Mahmud Al-Jalili, "Tarjamat Ibn Khaldun lil Maqrizi," Majallat AlMajma‘ Al-'Ilmi Al-'Iraqi, 13, 1966, pp. 215-246.

[4] Wan Kamal Mujani, "European technological innovation that surpassed Muslim technology of the medieval ages: an example during the Circassian Mamluk period," Acta Orientalia, 65(1), 2012, pp. 39-54.

[5] Muhammad Abdullah Inan, Mu'arrikhu Misr Al-Islamiyya wa Masadir Al-Tarikh Al-Misri, Cairo, Mu'assasat Mukhtar lil Nashr wa al-Tawzi`, 1991.

[6] Wan Kamal Mujani, W. M. H. W. Hussain, N. I. Yaakub and R. Abdul Rashid, The economic decline of Circassian Mamluks in Egypt, International Business Management, 2011, 5(6A), pp. 345-348.

[7] Wan Kamal Mujani, "The Nile and irrigation system during the Mamluk period (1468-1517)," Australian Journal of Basic and Applied Sciences, 2011 (Oct.), pp. 2264-2268.

[8] Wan Kamal Mujani, "The Fineness of Dinar, Dirham and Fals during the Mamluk period,” Journal of Applied Sciences Research, 2011, 7(12), pp. 1895-1900.

[9] Shams Al-Din Muhammad bin Abd Al-Rahman Al-Sakhawi, Al-Daw' Al-Lami` li Ahl Al-Qarn Al-Tasi‘, vol. III, 1935, Cairo, Maktabat AlQuds.

[10] Wan Kamal Mujani, "Environmental effects in the agriculture of medieval Egypt," Research Journal of Applied Sciences, 2011, 6(7-12), pp. 405-409.

[11] Muhammad bin Ahmad Ibn Iyas, Bada'i` Al-Zuhur fi Waqa'i` Al-Duhur, vol. 4, 1960, Cairo, n.p.

[12] Giorgio Levi Della Vida, Elenco dei Manoscritti Arabi Islamici Della Bibliotheca Vaticana, 1935, Roma, Tipografia del Senato del dott. G Bardi.

[13] Wan Kamal Mujani, R. Abdul Rashid, W. M. H. W. Hussain and N. I. Yaakub, "A Comparative studies between partition and sub-division of land under Mamluk Iqta ' system and Malaysian National Land Code 1965," Journal of The Social Sciences, 2012, 7(2), pp. 189-195. 
[14] Abd Al-Basit bin Khalil Shahin Al-Malati, Nayl Al-Amal fi Dhayl AlDuwal, Ms. Huntington 610, Oxford, The Bodleian Library.

[15] Wan Kamal Mujani, "Note on Western travellers' observations on Mamluk economy," Advances in Natural and Applied Sciences, 2012, 6(3), pp. 296-298.

[16] Wan Kamal Mujani, "The Expenses of Mamluk army during the Burji period," Advances in Natural and Applied Sciences, 2012, 6(3), pp. 303309 . 